\title{
III. Widerstand durch Trauer
}



Jürgen Manemann:

XR steht für eine neue Sensibilisierung der Politik, die uns für das Leid aller Kreaturen öffnet. Diese Sensibilisierung erfüllt mit Trauer. XR lehnt jeglichen Optimismus ab. Optimismus ist der bewusste oder unbewusste Versuch, Katastrophen zu überspielen. XR-Aktivist*innen verbindet die Erfahrung des Gefährdetseins: die Bedrohung der Erde und das massenhafte Sterben der Arten. Trauer über die Ausrottung des Lebens wird in dieser Bewegung zur Handlungsressource. XR will keine Kampfzonen schaffen. Im Gegenteil. Die Radikalität der Aktionen geht einher mit der Verpflichtung, keine Feindzonen entstehen zu lassen, geht es doch um den Schutz allen Lebens. XR versteht sich als Rebellion für das Leben: für die Menschen, die Tiere und die Pflanzen.

XR-Declaration of Rebellion*:

We hold the following to be true: This is our darkest hour. Humanity finds itself embroiled in an event unprecedented in its history, one which, unless immediately addressed, will catapult us further into the destruction of all we hold dear: 
"Hope dies - Action begins"

this nation, its peoples, our ecosystems and the future of generations to come.

Der XR-Aktivist, Schriftsteller und Schauspieler Sam Knights bringt die gegenwärtige Herausforderung klar und deutlich zum Ausdruck:

»The challenge we now face is extremely daunting. Because the problem, unfortunately, is not just the climate. The problem is ecology. The problem is the environment. The problem is biodiversity. The problem is capitalism. The problem is colonialism. The problem is power. The problem is inequality. The problem is greed, and corruption, and money, and this tired, broken system.«

... XR steht für Trauer, aber nicht für Resignation, sondern für Empowerment. Gregory Fuller plädiert für eine »heitere Hoffnungslosigkeit«, Slavoj Žižek für den »Mut zur Hoffnungslosigkeit«. Nicht so XR. XR steht für eine politische Haltung des Widerstands durch Trauer, die es uns ermöglicht, angesichts katastrophaler Zustände für ein humanes Leben zu kämpfen:

»Hope dies - Action begins«... 